TO REPAIR A BROKEN WORLD 



\section{TO REPAIR}

A BROKEN WORLD

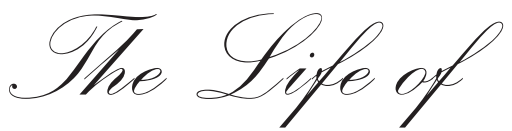

Henvietta Grold

FOUNDER OF HADASSAH

DVORA HACOHEN

Harvard University Press

Cambridge, Massachusetts \& London, England 202I 
English translation by Shmuel Sermoneta-Gertel, copyright ( $\odot$ 202I by Dvora Hacohen

Foreword by Ruth Bader Ginsburg, copyright ( $)$ 202I by Ruth Bader Ginsburg

First edition published in Hebrew as Manhiga le-lo Gvulot: Henrietta Szold-Biographia, Am Oved Books, Tel Aviv, 2019

ALL RIGHTS RESERVED

Printed in the United States of America

First printing

Cover illustration: Photograph of Henrietta Szold in I940 by Alexander Ganan, courtesy of the Pritzker Family National Photography Collection, The National Library of Israel, Abraham Schwadron collection.

Cover design: Gabriele Wilson

9780674259I7I (EPUB)

9780674259I 88 (PDF)

The Library of Congress has cataloged the printed edition as follows:

Names: Hakohen, Devorah, author. I Gertel, Shmuel Sermoneta, translator. I

Ginsburg, Ruth Bader, writer of foreword.

Title: To repair a broken world : the life of Henrietta Szold, founder of Hadassah/Dvora Hacohen; translated by Shmuel Sermoneta-Gertel ; foreword by Ruth Bader Ginsburg.

Description: Cambridge, Massachusetts : Harvard University Press, 202 . I

First edition published in Hebrew as Manhigah le-lo gevulot : Henriyețah Sold : biyografyah $=$ To repair a broken world : the life of Henrietta Szold. Tel Aviv :

Am Oved Books, 2019. I Includes bibliographical references and index.

Identifiers: LCCN 2020045447 I ISBN 9780674988095 (cloth)

Subjects: LCSH: Szold, Henrietta, I860-I945. I Jewish Agency for Israel.

Youth Aliyah Department. I Jewish women-Biography. I Zionists-Biography. I

Zionists-United States-Biography.

Classification: LCC DSI5I.S9 H34I3 202I I DDC 320.54095694092 [B]—dc23

LC record available at https://lccn.loc.gov/2020045447 
To my beloved children

Meron, Aviad, Hagit

And my grandchildren 
